\title{
How Home Loan Modification through the 60/40 Plan Can Save the Housing Sector
}

\author{
Manuel S. Santos
}

\begin{abstract}
Many well-respected economists have suggested plans for mortgage restructuring built on the idea of share appreciation mortgages, which generate rather complex transactions with conflicting interests between the lender and the homeowner. The 60/40 Plan, however, combines several economic principles adapted to the nature of home loans and appears to provide all the benefits but fewer of the drawbacks of many of these programs, including current government programs such as the Home Affordable Refinance (HARP) and Home Affordable Modification (HAMP) programs. For example, HARP homeowners must service the entire principal balance and meet additional eligibility restrictions that are not warranted by economic considerations. In contrast, the 60/40 Plan provides for affordable monthly payments by restructuring the debt into two parts, has relatively minor eligibility requirements, and creates household incentives to maintain the property. Failure to address the current financing needs of the housing market may result in a decapitalization of the banking sector, lost potential house value for many homeowners through foreclosure, and an extended episode of low growth for the U.S. economy. (JEL E44, E52, G01)
\end{abstract}

Federal Reserve Bank of St. Louis Review, March/April 2012, 94(2), pp. 103-15.

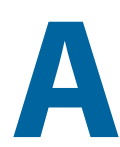
pproximately 55 million homes have a mortgage, with an outstanding balance of $\$ 9.5$ trillion (Goodman, 2011). In many areas of the country, housing prices have declined between 20 and 40 percent from peak values (Figure 1). And, as discussed in Garriga and Schlagenhauf (2010), declining house prices are highly correlated with home loan defaults (Figure 2). Mortgage default rates peaked at the end of 2009 and have not come down to normal values. Indeed, some analysts (e.g., Goodman, 2011) have estimated that, in the absence of policy changes, about 10 million borrowers are likely to default over the coming yearsexpanding the inventory of homes in an already soft selling market.

Currently, about 22 percent of homeowners are underwater: That is, the consolidated value of their mortgage debt is greater than the home value (Goodman, 2011). As discussed in a recent white paper from the Board of Governors of the Federal Reserve System (2012), underwater

Manuel S. Santos is the James L. Knight Chair of the Department of Economics at the University of Miami and a visiting scholar at the Federal Reserve Bank of St. Louis. This paper has benefited from various discussions and presentations, and the author is especially grateful to Carlos Garriga, David Kelly, and Adrian Peralta-Alva for very substantial comments.

(c) 2012, The Federal Reserve Bank of St. Louis. The views expressed in this article are those of the author(s) and do not necessarily reflect the views of the Federal Reserve System, the Board of Governors, or the regional Federal Reserve Banks. Articles may be reprinted, reproduced, published, distributed, displayed, and transmitted in their entirety if copyright notice, author name(s), and full citation are included. Abstracts, synopses, and other derivative works may be made only with prior written permission of the Federal Reserve Bank of St. Louis. 


\section{Figure 1}

\section{House Prices}

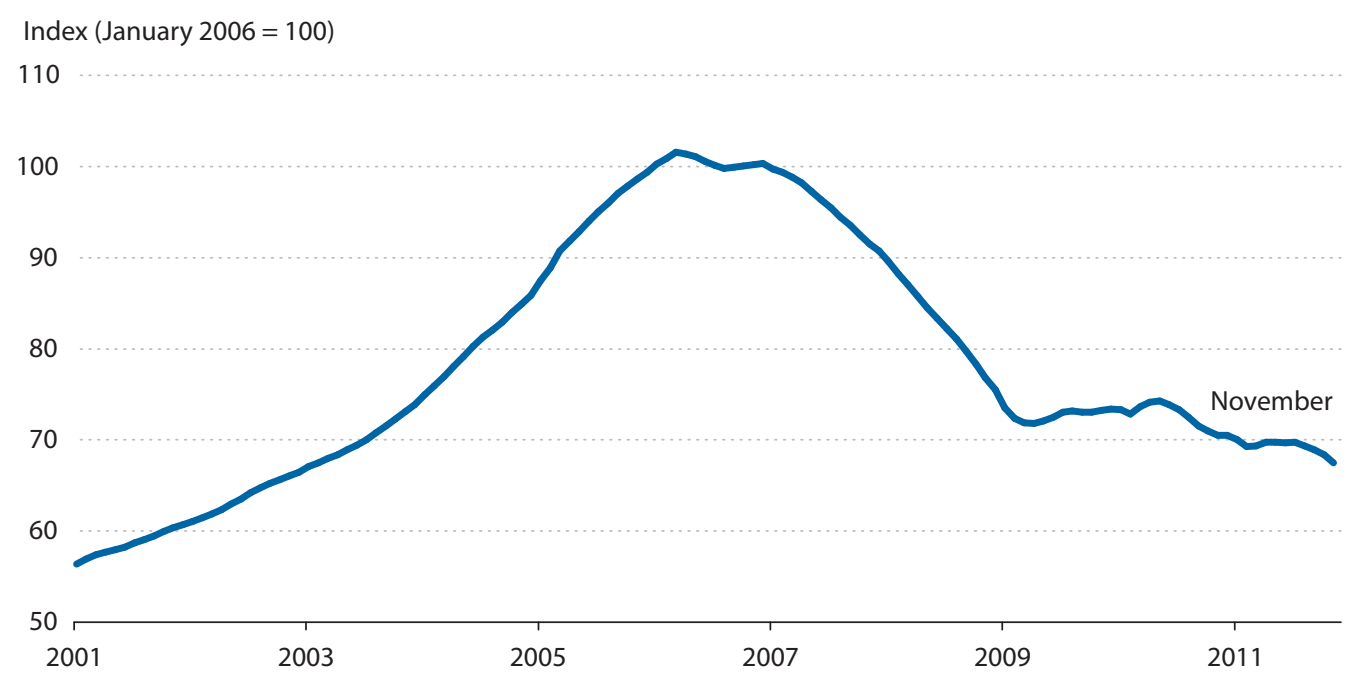

SOURCE: CoreLogic and Haver Analytics.

\section{Figure 2}

Mortgage Foreclosures Started: United States (seasonally adjusted)

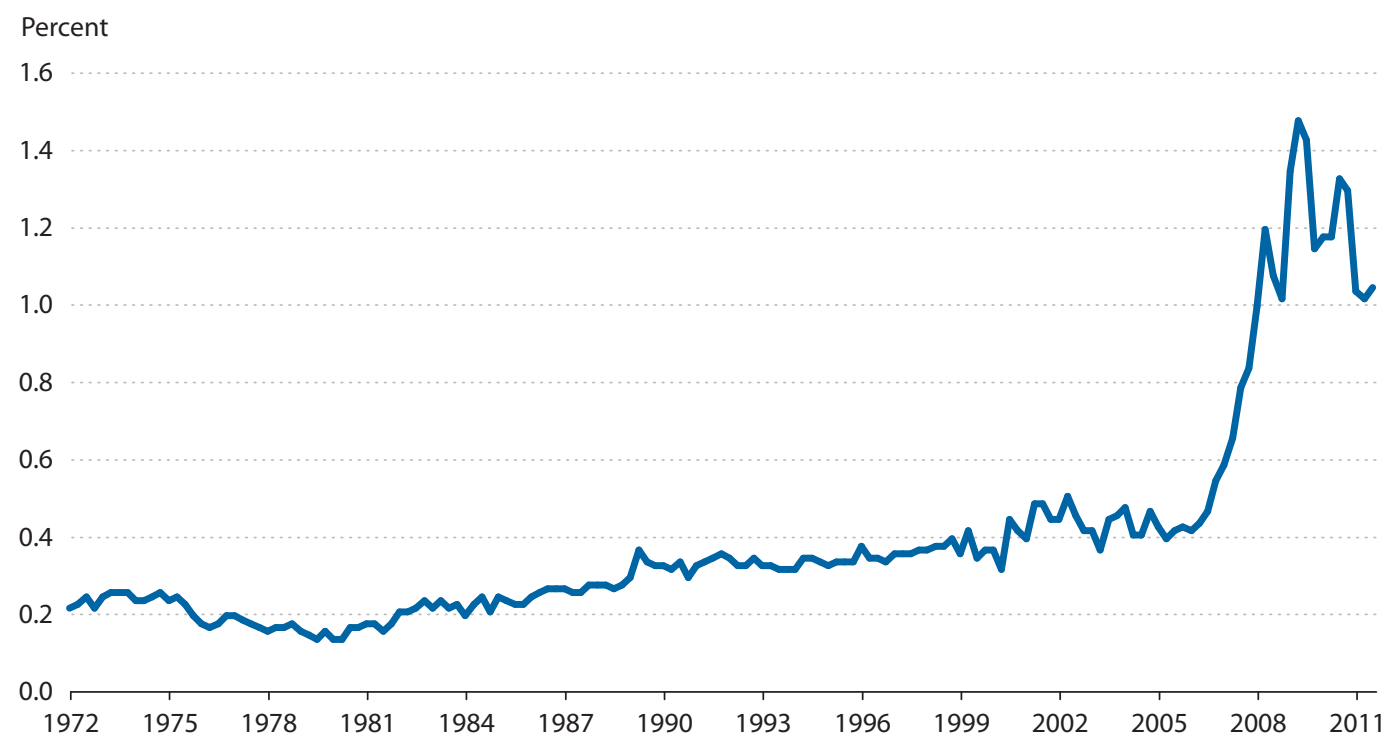

SOURCE: Mortgage Bankers Association and Haver Analytics. 


\section{Figure 3}

\section{U.S. Unemployment Rate}

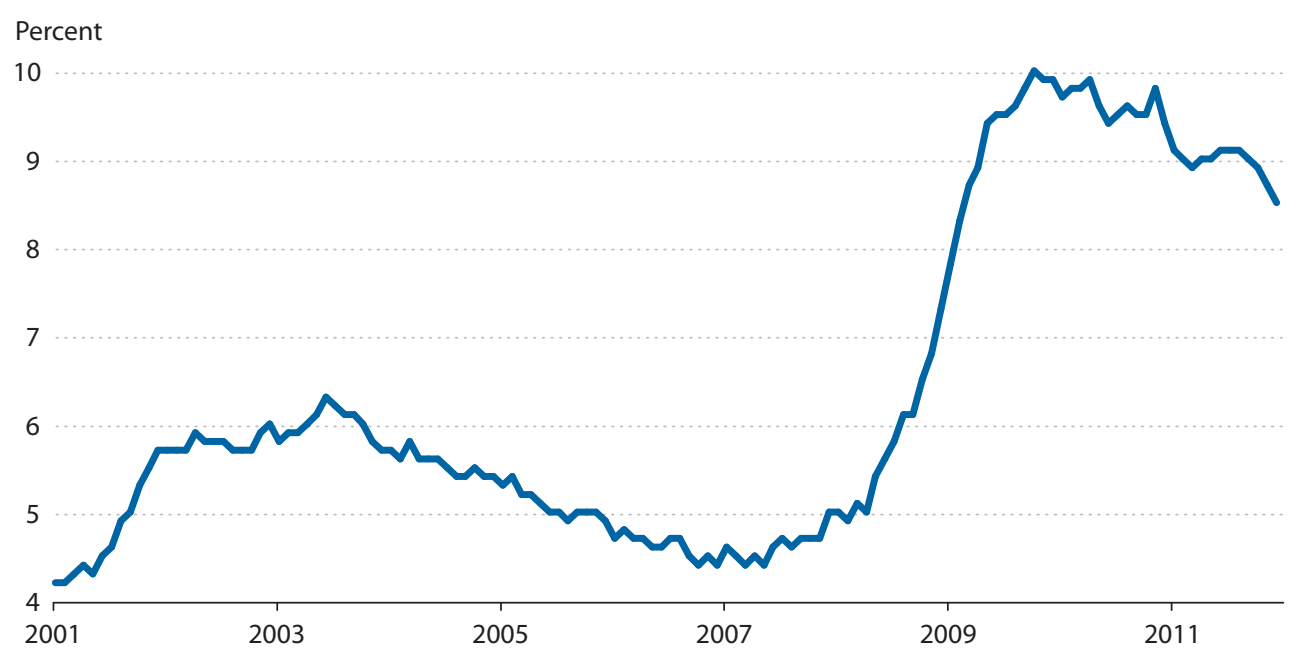

SOURCE: Bureau of Labor Statistics and Haver Analytics.

mortgages together with adverse economic conditions in the labor market-such as high unemployment (Figure 3) - and the inability to refinance or resell properties in an environment of declining prices appear to be the three main factors behind the high number of underperforming loans. A sizable group of homeowners may then be tempted to leave their properties, which in turn would further depress home prices. In this way, high unemployment rates, foreclosures, and declining home prices can have self-reinforcing effects.

Although interest rates have dropped to historical lows during the ongoing economic recovery, housing prices continue to decline. If new rounds of conventional expansionary monetary policy (e.g., quantitative easing) may have only a minor impact on the housing market, what are the possible solutions to this problem? This paper advocates for a new program for loan modification called the 60/40 Plan (Diaz, 2008, patent pending).

\section{MORTGAGES IN THE U.S. ECONOMY}

In addition to the recent recession, the nation experienced a severe banking crisis. Monetary history (especially the recent Japanese experience) shows that banking crises may have longlasting effects. Specifically, theoretical work in economics has revealed that markets fail to deal with problems of asymmetric information (adverse selection and moral hazard) in which the first-best outcome is usually not attainable. Some good assets may lose value because of unobserved characteristics or lack of due diligence. These assets are usually referred to as toxic assets and bad loans. And markets may be unable to overcome information problems in the trading and pricing of toxic assets: Economic agents may not truthfully reveal some asset characteristics or may not be willing to exert enough effort to protect the value of the asset. 
Figure 4

\section{U.S. Real GDP Growth Rate}

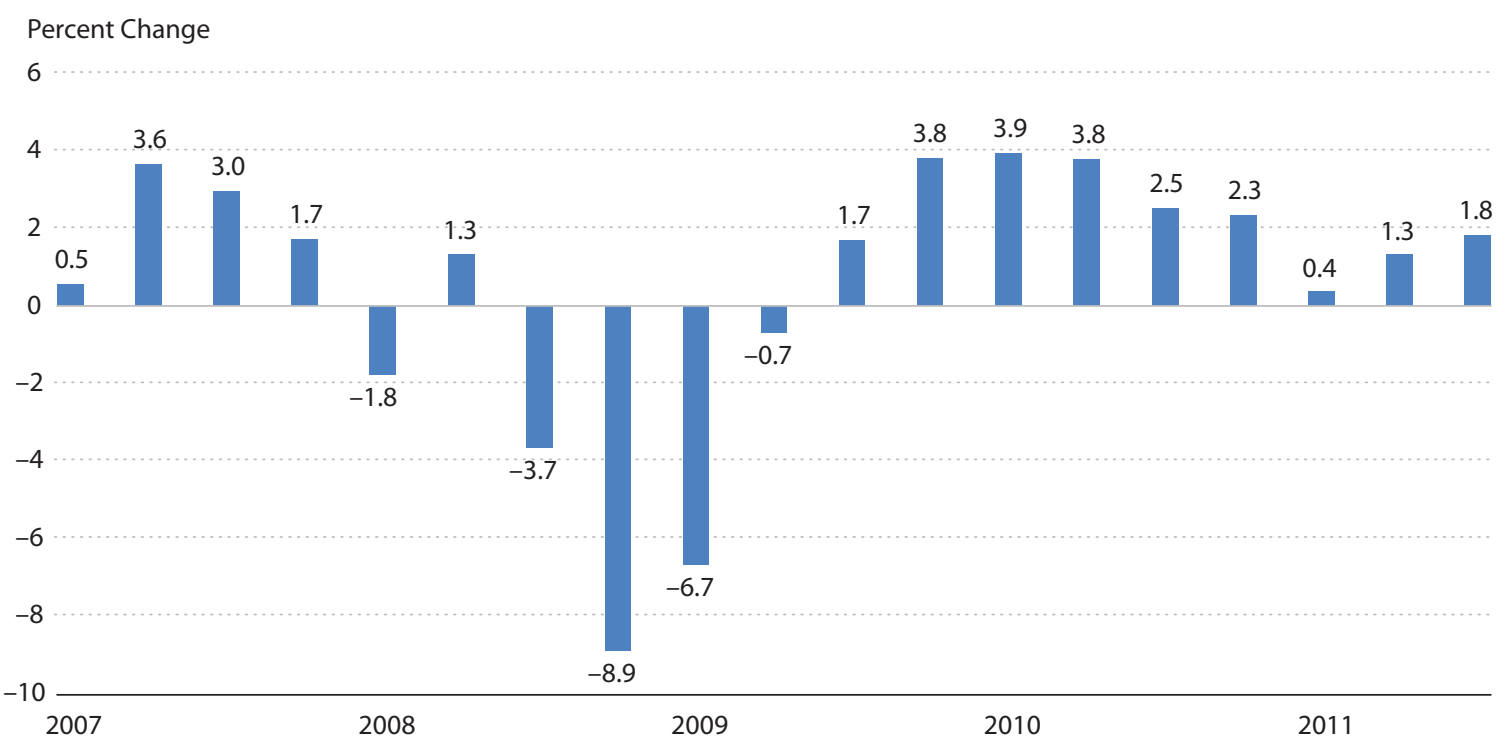

SOURCE: Bureau of Economic Analysis and Haver Analytics.

Economists have characterized several contractual mechanisms inducing truth-telling and optimal effort. Absent such underlying mechanisms, however, many situations exist in which the market collapses into simplistic pricing schemes that may include rationing-which may fit some agents but may leave many others unsatisfied with market outcomes. Therefore, economic theory predicts that, in the absence of adequate mechanisms, asymmetric information means market failure.

These theories obviously apply well to the housing sector: A mortgage is a collateralized loan on a home property, and the market value of this loan is thus bounded below by the value of that property (i.e., the collateral). Hence, a mortgage will not appear to be a toxic asset if it is backed by a tangible property whose worth is (or seems) fairly close to the nominal value of the loan. The home value, however, is endogenously determined by market considerations and the homeowner's maintenance of the property. Furthermore, a lender may face large transaction costs when dealing with an unmotivated homeowner. Therefore, a mortgage does contain various characteristics of a toxic asset, and the contract must be designed with the right incentives to promote efficiency; banks need to operate in environments in which homeowners are persuaded to make payments and maintain their homes.

But many homeowners have had the opposite experience, and the current wave of foreclosures has led to a great misallocation of economic resources. It has depressed the housing market, de-capitalized the banking sector, and may hamper economic growth. In fact, economic growth has been mild at best: Over the past few quarters, annualized U.S. gross domestic product (GDP) growth rates have been consistently below 3 percent (Figure 4). Extensive historical evidence 
shows that a lack of robust economic growth means that excessive unemployment is likely to persist.

The housing sector used to account for 20 percent of GDP growth. But after the market collapse of 2006-08, this sector has remained stagnant. Private single-family housing starts went from 1.8 million in 2006 to an annual average of 0.45 million in 2009-12 (Federal Reserve bank of Richmond, 2012). Likewise, according to the Bureau of Labor Statistics, construction employment has lost 2.2 million jobs and the rate of construction unemployment expanded to 16 percent-by far the highest of any sector. ${ }^{1}$ Currently, there are no signs that construction will recover soon, despite the fact that conventional measures of expansionary monetary policy have already delivered very acceptable interest rates.

Although mortgage rates are at historical lows, a great majority of households cannot secure loan modifications in line with the recent interest rate trends. Hence, both banks and households are trapped into inefficient borrowing arrangements that lead to excessive foreclosures and that have dragged the U.S. economy into a protracted cleansing period of debt overhang and low growth. Over 30 million households are facing rather high interest rates (Boyce, Hubbard, and Mayer, 2011) and would greatly benefit from further access to loan programs that reflect present economic conditions and housing prices.

Banks and the government monitor existing loan-modification programs. As I will discuss further, trading mechanisms propelled by these programs may actually convert some good loans into bad loans and expose the banking system and taxpayers to significant risks. Therefore, at the given prices for mortgage packages, it is more financially advantageous for private investors to buy those packages; banks could then clean their balances, and these investors could offer more realistic payment schedules to households.

In summary, the behavior of housing prices and loan delinquencies cannot be considered a business cycle event and will require some creative answers. The 60/40 Plan turns attention to credit market frictions caused by insufficient provision of collateral and asymmetric information.

\section{HOW THE 60/40 PLAN WORKS}

Basically, under the conditions of the 60/40 Plan, a mortgage loan would be restructured into a two-part single mortgage: Parts A and B. Ideally, the split for this program would be 60/40: That is, Part A would represent 60 percent of the actual mortgage debt, and Part B would represent the remaining 40 percent. Interest rates for both parts could be benchmarked to some Treasury bond. Part A of the modified mortgage would be financed and amortized by the homeowner, with 360 equal monthly installments. Part B of the same modified mortgage would be a zero-coupon balloon with all payments deferred until maturity.

It is important to understand that the 60/40 Plan builds on financial postulates and incentivecompatible mechanisms that can be firmly implemented. It is designed as a first-best contract between the homeowner and the lender by holding onto some basic principles of incentive theory. These defining principles make this plan a most attractive choice.

First, as noted, the 60/40 Plan divides the home loan into two parts, A and B. Part A operates as a traditional home loan, and Part B can be converted into a special purpose vehicle (SPV) that can be traded in the secondary debt market to pull liquidity into the housing market. Hence, the 
60/40 Plan does restructure the loan. Collateral for Part A stems from the home value coupled with the ability of the homeowner to comply with the proposed payment schedule. Collateral for Part B stems from the eventual liquidation of the home asset as well as additional government policies discussed here later.

Second, a homeowner is still liable for the entire amount of the principal balance. Hence, the 60/40 Plan does not target any given type of homeowner, nor does it impose any upfront payments on banks or taxpayers.

Third, the 60/40 Plan is meant to decrease homeowners' regular monthly payments by over 40 percent. As a matter of fact, given the current drop in interest rates, the 60/40 Plan may decrease monthly payments for a great majority of homeowners facing foreclosure by about 55 percent. Therefore, abandoning the property no longer becomes so attractive an option for homeowners.

Fourth, to qualify for the 60/40 Plan, a household must demonstrate the ability to honor the new payment schedule. The 60/40 Plan accepts current economic conditions. Consequently, eligibility criteria should focus on the ability to pay for the new loan monthly payments-rather than the ability to pay for the original, high-interest monthly payments-over the whole principal balance.

Fifth, the 60/40 Plan should be executed by private investors or banks with no direct government intervention. The plan outlines a way for investors to negotiate with the banks and mortgage corporations that hold the existing mortgages to create a special mortgage fund.

And sixth, the 60/40 Plan allows for government tax incentives and other policies over the 30 -year life of the loan such as the existing system of deductible home mortgage interest. Part A may be subject to the same type of deferred interest deduction currently available in the United States. Part B may be given a similar tax treatment or may be subject to other measures that enhance transparency and confidence in financial markets. Hence, the 60/40 Plan does not require any current government outlays, but it recognizes the importance of government policies to revitalize financial and housing markets.

\section{An Example}

At this point, it seems helpful to provide a simple example. I first focus on the decision problem of the homeowner and then, in the next sections, anticipate some ways in which the government and investors may take part in this process. (Here, for illustrative purposes, Part A of the mortgage will carry a fixed interest rate of 5 percent for the life of the loan and Part B will carry a fixed interest rate of 4 percent. Part B's lower interest rate limits growth of the deferred payment.)

In 2006, the Smith family bought a home that matched their needs very well and that they were qualified to buy; they bought it for $\$ 500,000$. The purchase was financed with a collateralized loan for $\$ 400,000$. The mortgage came in the form of a typical 30 -year loan that carries a fixed interest rate of 7 percent: In other words, a fixed-rate mortgage with 360 equal monthly payments of $\$ 2,661$. Unfortunately, when the subprime financial crisis hit the labor and housing markets in 2007, the market value of their home plummeted to $\$ 300,000$, which is a 40 percent depreciation from the original purchase value.

Thus, the Smiths purchased the home for $\mathrm{V}=\$ 500,000$ under a 30 -year fixed-rate mortgage with balance $\mathrm{D}=\$ 400,000$. They committed to monthly payments of $\$ 2,661$ and must honor 
these loan obligations or else risk losing the property. The default option at the time of purchase was $\max \{\mathrm{V}-\mathrm{D}, 0\}=\{\$ 100,000,0\}=\$ 100,000$. After the decline in home prices, the Smiths' default option became $\max \left\{\mathrm{V}^{\prime}-\mathrm{D}, 0\right\}=\{-\$ 100,000,0\}=0$. Thus, by leaving the property, they would rid themselves of the existing negative equity.

Yet, as long as the Smiths can afford the monthly payments, there is no need to consider default-not even a strategic default. In this example, however-as in many recent real-life examples-one member of the family is laid off and the family loses the income from that job. Suddenly, monthly loan payments have become too taxing for the projected family income; moreover, the Smiths cannot sell the home because they are underwater.

Renting a comparable home in the neighborhood would now cost about $\$ 1,500.2$ Therefore, the current loan servicing payments exceed the monthly rental payments by $\$ 1,161$. At the time the Smiths bought the home, the economic prospects regarding labor earnings were quite different, and the goal was to benefit from appreciating home values compared with a very steep profile of rental payments.

At that time, renting a similar property was about $\$ 2,100$. But the Smiths were able to lock in a fixed monthly payment for $\$ 2,661$ with a bank and avoid steep increases in future rental values. Again: The 60/40 Plans assigns 60 percent of the principal balance to Part A and 40 percent of the principal balance to Part B. Hence, in our example, the debt assigned to Part A would be $\$ 240,000$, and the debt assigned to Part B would be $\$ 160,000$. As already discussed, the debt corresponding to Part A of the modified mortgage will be financed and amortized by the homeowner under 360 equal monthly installments. At the proposed interest of 5 percent, this corresponds to a monthly payment of $\$ 1,288$. Therefore, the following choices can now be offered to the Smiths:

$\begin{array}{lccc} & \begin{array}{c}\text { Remain, pay } \\ \text { current mortgage }\end{array} & \begin{array}{c}\text { Leave, rent a } \\ \text { comparable home }\end{array} & \begin{array}{c}\text { Remain, pay } \\ 60 / 40 \text { Plan mortgage }\end{array} \\ \text { Monthly payment: } & \$ 2,661 & \$ 1,500 & \$ 1,288\end{array}$

It should be observed that these computations do not take into consideration maintenance costs, home insurance, property taxes, fiscal interest deductions for homeowners, and transaction costs of leaving the property. As a general rule in Florida and other states with similar property taxes, savings from the deductible home mortgage interest wash out with property taxes. Hence, renting a comparable home may be slightly more costly than preserving the current home through the 60/40 Plan. Further, the 60/40 Plan monthly payment is fixed: Rental monthly payments will be updated by inflation over a period of 30 years. Finally, note that the 60/40 Plan brings a 52 percent decrease in the monthly payment over the original loan-that is, the monthly payment drops from $\$ 2,661$ to $\$ 1,288$.

There is, of course, the Part B portion of the original mortgage; that amounts to $\$ 160,000$ in debt at an interest rate of 4 percent. As already pointed out, Part B is a zero-coupon balloon with all payments deferred until maturity. This is the evolution of future balances: 


\begin{tabular}{lc} 
End of year $\mathbf{T}$ & Future balance \\
\hline$T=10$ & $\$ 236,839$ \\
$T=16$ & $\$ 299,677$ \\
$T=20$ & $\$ 350,580$ \\
$T=30$ & $\$ 518,944$
\end{tabular}

Finally, let's see how the future balances of Parts A and B interact with home market values. Recall that the initial home market value is $\$ 300,000$, and for simplicity the underwater mortgage has a current balance of $\$ 400,000$. Hence, there is a negative equity value of $\$ 100,000$. Then, assume that over the 30-year life of the loan, home values appreciate at an average annual rate of 2.75 percent. Therefore:

\begin{tabular}{lcccc} 
End of year T & $\begin{array}{c}\text { Part A balance } \\
\text { (negative) }\end{array}$ & $\begin{array}{c}\text { Part B balance } \\
\text { (negative) }\end{array}$ & Home market value & Net equity \\
\hline $\mathrm{T}=0$ & $\$ 240,000$ & $\$ 160,000$ & $\$ 300,000$ & $(\$ 100,000)$ \\
$\mathrm{T}=10$ & $\$ 195,221$ & $\$ 236,839$ & $\$ 393,495$ & $(\$ 38,565)$ \\
$\mathrm{T}=16$ & $\$ 155,437$ & $\$ 299,677$ & $\$ 463,053$ & $\$ 7,939$ \\
$\mathrm{~T}=20$ & $\$ 121,469$ & $\$ 350,580$ & $\$ 516,129$ & $\$ 44,080$ \\
$\mathrm{~T}=30$ & $\$ 0$ & $\$ 518,944$ & $\$ 676,981$ & $\$ 158,037$
\end{tabular}

In summary, Part A of the 60/40 Plan offers a 30-year schedule with equal monthly installments. This payment schedule dominates renting and allows the homeowner to stay in the home for the 30-year period. Part B of the 60/40 Plan is the remaining debt balance in which all payments are deferred until the terminal date. This part must be liquidated using the home property as collateral. For reasonable projections of home market values, the 60/40 Plan turns negative equity (i.e., an underwater mortgage) into positive wealth.

\section{HOW THE 60/40 PLAN COMPARES WITH OTHER REFINANCING PROGRAMS}

\section{Government Programs to Fight the Mortgage Crisis}

It is unlikely that the answer to the current wave of home-loan defaults will come from mechanisms directly monitored by the government. Notwithstanding, the government can play an important role in this process by holding onto policies that may restore confidence in the housing market. Indeed, policies could have a sudden impact on financial markets without current government outlays. Relatively few homeowners have accessed programs such as HARP and HAMP. Hence, these programs have not been so successful in bringing banks and homeowners to the table and are bound to have a rather limited influence on the housing market and the economy. Additional programs that favor certain groups (e.g., those that subsidize unemployed households) will reach only a relatively small fraction of the population and may become quite costly. 
The purpose of the HARP program is to help homeowners benefit from these standard forms of bank refinancing, given current trends in interest rates. Several rules, however, are involved in the qualifying process that may restrain participation; these rules are not well grounded in economic theory. For instance, a homeowner must be up to date with all loan payments. This eligibility condition acts as a screening device to favor homeowners who could afford the monthly payments of the original, high-interest-rate loan.

Of course, there is a hidden flaw in some proposed refinancing programs, since there is no debt restructuring and the loan-to-value ratio may actually be greater than one. The 60/40 Plan presupposes that only 60 percent of the loan falls into the category of a standard mortgage. The pricing of the remaining 40 percent of the loan (i.e., Part B) is a rather delicate issue in which government policies may be instrumental to ensure low interest rates.

\section{Share Appreciation Mortgage Programs}

There are various proposals endorsed by very well-respected academics $\underline{\underline{3}}$ that build on some type of debt restructuring. The idea is to tailor a new loan commensurate with the property. Then, the debt write-off must be borne by either the bank or the government. Additional clauses may allow the bank or taxpayer to recoup some of the debt write-off as the home later appreciates. Besides the potential losses and the liquidity drain that can be imposed on the banking system to finance a debt restructuring, share appreciation mortgage (SAM) programs generate perverse incentives. A solvent homeowner may thus wish to renegotiate the loan and impose a capital loss on the bank. Also, the homeowner is not fully motivated when it comes to the preservation of the home and the handling of home repairs since the owner is no longer the sole proprietor.

If debt is restructured to 60 percent of the original book value, the SAM program carries the same 30-year payment schedule as the 60/40 Plan. In this benchmark case, the SAM program transfers all initial negative equity to the bank, which will be reflected in the bank balances, unless the government pays back the bank. This drain of liquidity goes against established property rights and forces banks to absorb capital losses from solvent homeowners. Hence, the SAM program needs an initial investment by an independent entity and then develops a regime of fractional ownership with conflicting interests between the bank and the original homeowner.

These conflicting interests appear at the time of negotiating for the share of fractional ownership - and subsequently for managing the property and regaining the investment. Given government's limited funding capabilities and the current state of the banking system, SAM programs are simply not feasible.

\section{Bank Programs}

Several banks have offered favorable conditions on home loan refinancing to help their most needy borrowers remain in their homes. These bank programs may include lowering interest payments, restructuring principal payments and the maturity of the loan, and principal writeoffs. This approach of bank forgiveness goes against basic economic intuition. Since the most attractive offer of forgiveness is available to the worst performers, households have an incentive to stop payments to receive more favorable terms.

Rather than debt restructuring, a bank could offer an interest-only loan refinancing over the 30 -year period. Then, for a 5 percent interest rate, a mortgage of $\$ 400,000$ requires a monthly 
payment of $\$ 1,666$. Hence, an interest-only 30 -year loan offers a payment schedule that is 20 percent higher than that of the 60/40 Plan. In both cases, at the end of the term the loan must be liquidated using the property as collateral. Usually, banks cannot offer these contracts because they act as "servicers" or intermediaries in the mortgage market.

The advantage of the 60/40 Plan is that it splits the loan into Parts A and B. Indeed, Part B can be considered as an additional SPV to be traded in the secondary debt market and to be regulated as an independent entity. Of course, the bank can also offer a standard refinancing of the $\$ 400,000$ at a fixed interest rate of 5 percent for 30 years. In such a case the monthly payment goes to $\$ 2,147$. This is a 70 percent increase in the monthly payment over the $60 / 40$ Plan. Under this fixed-rate mortgage program the homeowner debt would be zero by the end of the 30 -year period.

\section{GOVERNMENT POLICIES}

At present, the federal government offers a tax allowance for interest payments on home loans for up to $\$ 1$ million for a primary residence (or even a second home). In the present economic conditions with a small volume of transactions, this tax benefit would favor homeowners as opposed to those living in a rental property and can be applied to Part A of the mortgage. A similar incentive scheme applied to Part B would limit the growth of the zero-coupon balloon. For instance, suppose that the federal government can afford an interest subsidy so that the actual rate faced by the homeowner is 2.75 percent rather than the 4 percent in our original example. Then, at the terminal date $\mathrm{T}=30$, the remaining balance of Part B would be $\$ 361,056$ rather than $\$ 518,944$. Even in the presence of this interest-rate subsidy, the $60 / 40$ Plan may bring additional revenues to the government because of the lower interest rates that factor into the home loan deductible. Hence, I have assessed that increasing the interest rate subsidy to 2 percent for Part B (which would impose an interest rate of 2 percent) would cost the government about an extra $\$ 15$ billion, which is about 1 part per thousand dollars of U.S. GDP.

Contrary to what most economists seem to believe, homeowners do not greatly benefit from the current tax system. A serious problem with home ownership in many states such as Florida is that property taxes are quite high-as is home insurance. Hence, in those states with rather high property taxes, it may be of interest to shift to state income taxes or to sale taxes in order to boost the housing market. As a matter of fact, the theory of optimal taxation suggests that it is not optimal to tax capital.

As discussed above, the successful operation of Part B hinges on low interest rates, which may occur as an outcome of optimal provision of public collateral or deposit insurance. In light of the low Treasury rates, this is an opportune time for the implementation of the 60/40 Plan. The present economic crisis has brought down mortgage rates, the benefits of which need to be passed on to homeowners. Given the current state of the banking system and the uncertainties surrounding the economy, government intervention may channel liquidity to the housing market. The economic theory of bank runs and panics suggests that some type of FDIC support may be necessary to escape a bad equilibrium. Hence, economic policy should focus on the provision of quality collateral and insurance to transform savings into productive investments. This is actually easier to accomplish for Part B of the 60/40 Plan since all payments are deferred until the terminal date. 
Under reasonable estimations for labor mobility, migration flows, home transactions, and the evolution of home prices, it is almost certain that most of the existing set of mortgages will disappear long before the 30-year period.

The 60/40 Plan envisions some type of government intervention in the form of FDIC insurance. More specifically, the 60/40 Plan requests that the government authorize the FDIC to issue tax incentive rescue vouchers to the participating institutions for the full value of the Part $B$ portion in a special mortgage trust. Then, the participating institutions should issue the debtbacked securities to private investors. The idea is to allow lending institutions in charge of Part B loans to secure all needed liquidity from the general public. With the appropriate government collateral and instruments in the secondary debt market, consumers would be willing to channel their savings to the housing market at low interest rates. The 60/40 Plan does not contemplate any type of government funding.

In more general terms, the decline in home prices has raised the required home collateral value to about $\$ 2$ trillion. It is therefore an important challenge of economic policy (see Geanakoplos, 2010) to set up the right instruments and incentives for the provision of the missing collateral to help homeowners benefit from the current low interest rates and bolster the housing sector.

\section{CONCLUDING REMARKS}

Building on basic economic theory, this article has examined various aspects of the $60 / 40$ Plan and competing refinancing programs. The plan is intended to stop the lingering wave of foreclosures damaging the U.S. economy and to pass on the current low interest rates to homeowners who are unable to restructure their debts because of the loss of the collateral value and adverse conditions in the labor market.

Under the 60/40 Plan, mortgage loans are restructured ${ }^{4}$ into a two-part single mortgage: Parts A and B. Part A represents 60 percent of the actual mortgage debt, and it operates as a 30 year fixed-rate mortgage. For many areas in the United States, there is enough collateral in the property to accommodate the Part A portion of the loan. This collateral value is enhanced by the homeowner's income, which provides for the proposed payment schedule. Part B represents 40 percent of the actual mortgage debt, and it operates as a zero-coupon balloon loan in which all payments are deferred until maturity. The collateral for this part stems from the ability of the bank to liquidate the property at the end of the terminal date or upon default of the contract. The plan also acknowledges the importance of the government to provide further collateral: Part B can be instrumented as an SPV (with some type of FDIC provision) to channel liquidity to the housing market.

Given that housing prices have dropped about 33 percent from peak values, the 60/40 Plan adjusts the monthly payment to a point below the opportunity cost of moving to a similar rental property. (This opportunity cost would include the rental payment for a comparable property plus associated transactions costs.) Apart from this individual rationality constraint, the plan embeds other desirable mechanisms to promote an efficient contract between the bank and the homeowner, and it calls for government coordination efforts to pass on the current low interest rates to households. 
Accordingly, the 60/40 Plan may reduce mortgage monthly payments by about 50 percent, which would benefit a great majority of homeowners facing unfavorable loan conditionsespecially foreclosure-and would circumvent current refinancing hurdles surrounding the financial sector and government lending agencies. Second, the 60/40 Plan preserves existing property rights. This is a healthy start for every society-preventing adverse actions and demoralizing behavior among banks, homeowners, and taxpayers. Third, the 60/40 Plan is voluntary and should work for those households that could actually meet the proposed payment schedule. It presents a self-financed method to stop foreclosures and allows homeowners to convert negative equity into positive wealth under a stable financing arrangement over 30 years. And finally, the plan does not require any government outlays, but recognizes that government policies could be critical to restore confidence in the housing sector. As U.S. Treasury rates have reached historical lows, this is optimal timing for the implementation of a plan that would benefit a great majority of homeowners and stimulate the economy.

The economic theory of bank runs highlights the role of collateral and deposit insurance to coordinate expectations toward the good equilibrium. Hence, with the appropriate government collateral instruments in the secondary debt market, consumers would be willing to channel their savings to the housing market at low interest rates. The 60/40 Plan provides such an SPV to attract liquidity.

Similar monthly payment schedules could be generated by related refinancing schemes such as the debt restructuring involved in a typical SAM program. The SAM program, however, shifts the initial negative equity to the bank/government - which, at the present time, may not be feasible-and motivates the most solvent homeowners to take advantage of the bank's new weak position. At a later stage, the SAM program turns into a regime of fractional ownership in which one owner (the bank) will not be making use of the property and is simply interested in capital appreciation. In order words, the SAM program fails to admit that the original homeowner should be awarded all benefits of home appreciation stemming from maintenance, protection, and upgrading of the property. Therefore, the bank should issue a debt contract contingent upon general economic conditions, whereas the homeowner should hold full stake in the property. This is precisely at the heart of the defining principles of the 60/40 Plan.

Some loan-modification programs by governments and banks do not restructure the debt, and hence the mortgage contract may lack enough collateral and must be priced accordingly. U.S. banks often act as "servicers" or intermediaries in the mortgage market. In these cases, a home-loan modification may be accomplished only through prepayment.

The earlier example dealt with a primary loan. But all defining principles of the 60/40 Plan can be extended to more complex scenarios. More specifically, the present discussion has ignored several issues contemplated in the 60/40 Plan: HELOCs (home equity lines of credit), reverse mortgages, the sale of the property, and government measures to secure protection of property rights and the provision of collateral. For instance, if the resale of a property comes with positive equity, then the mortgage may be transferred to the new owner. In the case of negative equity, however, the trade of the home may not be feasible. This characteristic of the 60/40 Plan is nevertheless in line with its defining principle that the burden of the debt should fall on the original homeowner. As discussed in a white paper from the Board of Governors of the Federal Reserve System (2012), it is not clear that this limitation has important quantitative effects on the economy. 
If a given shock were to perturb the economy, then desired adjustments to restore efficiency could be effected at relatively low costs as long as some workers are movable.

Finally, other macroeconomic scenarios could be contemplated, as could changes in home prices, the relative weights assigned to Parts $\mathrm{A}$ and $\mathrm{B}$, and projections of future home prices. For the given current home prices and interest rates in the United States, the underlying parameters of the 60/40 Plan seem quite realistic and achievable.

\section{NOTES}

1 In addition to direct jobs and investment, one has to consider spillover effects of the construction sector plus the loss of consumption from the wealth effect of home price depreciation.

$\underline{2}$ Rental values vary with property taxes, which are not uniform across states; here, I present a fairly conservative estimate so the annual rental payment amounts to 6 percent of current market value and, hence, a price-to-rental ratio of 16.66.

$\underline{3}$ For instance, see Alpert, Hockett, and Roubini (2011), Caplin et al. (2008), Feldstein (2011), and Posner and Zingales (2009).

4 The need for debt restructuring is well understood in the corporate world (e.g., Frey, 2011, p. 244). Mortgage "cramdowns" have gained currency after the subprime financial crisis. The 60/40 Plan proposes loan restructuring without condoning debt.

\section{REFERENCES}

Alpert, Daniel; Hockett, Robert and Roubini, Nouriel. "The Way Forward." New America Foundation, October 10, 2011; http://newamerica.net/publications/policy/the_way forward.

Board of Governors of the Federal Reserve System. "The U.S. Housing Market: Current Conditions and Policy Considerations." White paper, January 4, 2012; http://federalreserve.gov/publications/other-reports/files/housing-white-paper-20120104.pdf.

Boyce, Alan; Hubbard, Glenn and Mayer, Chris. "Streamlined Refinancing for Up to 30 Million Borrowers." Unpublished manuscript, Columbia University, September 2011; http://absalonproject.com/wp-content/uploads/2011/09/BHM-V11-final.pdf.

Caplin, Andrew; Cooley, Thomas; Cunningham, Noel and Engler, Mitchell. "We Can Keep People in Their Homes." New York Times, October 29, 2008; http://online.wsj.com/article/SB122523972217878309.html.

Diaz, Gustavo. "60/40 Zero Coupon Rescue Plan." Patent pending, October 2008; http://6040theplan.com.

Federal Reserve Bank of Richmond. "National Economic Indicators." January 2012; www.richmondfed.org/research/national economy/national economic indicators/index.cfm.

Feldstein, Martin S. "How to Stop the Drop in Home Values." New York Times, October 12, 2011; www.nytimes.com/2011/10/13/opinion/how-to-stop-the-drop-in-home-values.html.

Frey, William A. Way Too Big to Fail: How Government and Private Industry Can Build a Fail-Safe Mortgage System. Greenwich, CT: Greenwich Financial Press, 2011.

Garriga, Carlos and Schlagenhauf, Don E. "Home Equity, Foreclosures, and Bail-Out Programs during the Subprime Crisis." Unpublished manuscript, Federal Reserve Bank of St. Louis, September 2010.

Geanakoplos, John. "Solving the Present Crisis and Managing the Leverage Cycle." Cowles Foundation Discussion Paper No. 1751, January 2010; http://cowles.econ.yale.edu/P/cd/d17b/d1751.pdf.

Goodman, Laurie S. Testimony before the United States Senate Subcommittee on Housing, Transportation, and Community Development of the Senate Committee on Banking, Housing and Urban Affairs. "New Ideas to Address the Glut of Foreclosed Properties," September 20, 2011; http://banking.senate.gov/public/index.cfm?FuseAction=Hearings.Hearing\&Hearing ID=16fe36f4-a0d1-4ef1-9a1994a2a9f85e1a.

Posner, Eric A. and Zingales, Luigi. "A Loan Modification Approach to the Housing Crisis." American Law and Economics Review, 2009, 11(2), pp. 575-607. 
Close

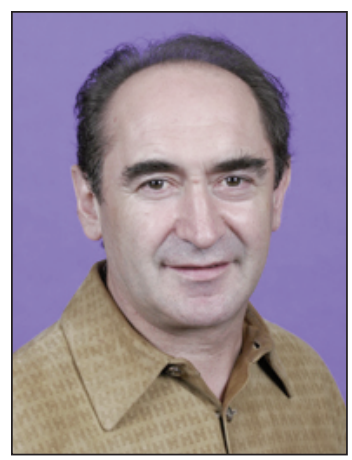

\section{Manuel S. Santos}

James L. Knight Chair of the Department of Economics at the University of Miami, and visiting scholar at the Federal Reserve Bank of St. Louis

http://www.bus.miami.edu/faculty-and-research/faculty-directory/economics/ santos/index.html

\section{Research Focus}

Manuel Santos' main areas of research are growth and development, computation, money, and financial markets.

\section{Recent Research}

"Numerical Simulation of Nonoptimal Dynamic Equilibrium Models,", Federal Reserve Bank of St. Louis Working Paper, 2009-018C.

"Currency Speculation in a Game-Theoretic Model of International Reserves," University of Miami Working Paper 2011-2. 